\title{
Histology of Watersnake (Enhydris Enhydris) Digestive System
}

\author{
Dian Masyitha ${ }^{1, *}$, Lena Maulidar ${ }^{2}$, Zainuddin Zainuddin ${ }^{1}$, Muhammad N. Salim³ ${ }^{3}$, Dwinna Aliza ${ }^{3}$, Fadli A. Gani ${ }^{4}$, \\ Rusli Rusli ${ }^{5}$ \\ ${ }^{1}$ Histology Laboratory of the Faculty of Veterinary Medicine, Syiah Kuala University, Banda Aceh 23111, Indonesia \\ ${ }^{2}$ Veterinary Education Study Program Faculty of Veterinary Medicine, Syiah Kuala University, Banda Aceh 23111, Indonesia \\ ${ }^{3}$ Pathology Laboratory, Faculty of Veterinary Medicine, Universitas Syiah Kuala, Banda Aceh, Indonesia \\ ${ }^{4}$ Anatomy Laboratory, Faculty of Veterinary Medicine, Universitas Syiah Kuala, Banda Aceh, Indonesia \\ ${ }^{5}$ Clinical Laboratory of the Faculty of Veterinary Medicine, Universitas Syiah Kuala, Banda Aceh, Indonesia
}

\begin{abstract}
This research aimed to study the histology of the digestive system of the watersnake (Enhydris enhydris). The digestive system taken was the esophagus, stomach, frontal small intestine and the back of the large intestine from three watersnakes. The samples were then made into histological preparations with hematoxylin-eosin (HE) staining and observed exploratively. The results showed that the digestive system of the watersnake was composed of layers of tissue, namely the mucosa, tunica submucosa, tunica muscularis, and serous tunica. Mucosal mucosa consisted of the lamina epithelium, lamina propria, and mucous lamina muscularis. The submucosal tunica consisted of connective tissue with blood vessels, lymph, and nerves. The muscular tunica was composed of circular muscles and elongated muscles. The serous tunica consisted of a thin layer of connective tissue that was covered by a thin layer of the mesothelium (mesothelium). The histological structure of the snake digestive system is not much different from the reptile digestive system. However, in the small intestine of the snake, Brunner, and liberkhun glands are not found. Lamina epithelial in the small intestine of the snake is composed of the layered cylindrical epithelium.
\end{abstract}

Keywords: watersnake, esophagus, stomach, small intestine, large intestine, histology.

\section{Introduction}

Snake is a type of vertebrate reptile (vertebrate) consisting of many species [1]. Snakes include vertebrates that are covered with scales, internally fertilized, and have eggshells. Skin covered with scales causes snakes to minimize loss of body fluids and can survive in a dry terrestrial environment [2]. Snakes are groups of animals from members of the order Squamata, class of reptiles. These reptiles generally live close to the water and are often found in and around rivers [3].

Snakes can live close to the human environment, such as in the yard of the house, gardens, fields, fields, forests, swamps, rivers, caves, beaches, and seas that have humid temperatures [4]. Snake shapes are generally elongated not legged, have any earholes, but have a very sensitive feeling. In some types of snakes, some organs can capture the radiant heat. The body color of snakes is generally brown, gray, or black, but there are also bright red, yellow, or green snakes with varying spots/spots/bracelets/lines [5].

One of the snakes found in the pond is the rainbow water snake (Enhydris enhydris). Rainbow water snake (Enhydris enhydris) has a relatively moderate body, a maximum length of $80 \mathrm{~cm}$, most questions between 50-60 cm. Small-headed, a rather large belly, and short-tailed. The back (dorsal) is generally light brown to blackish gray. The lower side of the body (lateral) is bright yellow or whitish. The lower side of the body (ventral) is yellowish or whitish, sometimes with faint spots or lines along its midline [6].

The digestive tract consists of the esophagus, stomach, small intestine and large intestine, each of which consists of mucosa, submucosa, muscularis, and serosa. The esophagus or esophagus is a simple short tube, in which the epithelial layer of the esophageal mucosa is formed from ciliated columnar and goblet cells [7]. The reptile digestive tract is elongated, starting from the mouth, esophagus, stomach, intestine, and cloaca. The shape of a reptile's stomach has different shapes, depending on its body shape. In snakes, it has an elongated stomach shape [8].

The digestive tract of reptiles is similar to other vertebrates. Reptiles have a variety of intestinal forms depending on the reptile group, there is a longitudinal transverse shape, zig-zag or nutlike pattern (shaped like a honeycomb). The epithelial layer of the small intestine is formed from columnar cells and goblet cells. In the reptile's intestine, it is very difficult to distinguish the part of the small intestine because it does not appear specific barriers between the intestines [9].

The histological structure of an animal's stomach usually consists of four parts, namely the tunica mucosa, submucosa tunica, muscularis tunica, and serous tunica. Mucosal tunica consists of

* Corresponding author: dianmasyitha@unsyiah.ac.id 
lamina epithelium, lamina propria, and mucosal muscularis. The surface of the stomach is covered with a layer of columnar epithelium that extends inward and covers the gastric pit, which is the tubular surface epithelial folds. The outer border of the mucosa is a thin smooth muscle in the form of a mucosal muscularis, which consists of an inner circular layer and an outer longitudinal layer [10].

The intestine is part of the digestive tract that plays a role in the process of digestion, absorption, and excretion of leftovers. The mucosal surface of the digestive tract, from the stomach to the colon is covered by a layer of mucus, which is gel-shaped and is viscoelastic. The mucus layer functions to lubricate the intestinal mucosa and protect from damage and invasion of pathogens [11].

Information about reptile histology is still very little, including studies of the reptile digestive system. According to Hamny et al [12], the similarities and differences in the structure and function of digestive organs between mammals and reptiles have not yet been studied, especially for the digestion of water snakes (Enhydris enhydris) that have never been reported. Therefore, it is necessary to conduct a study to get a histological picture of the digestive system in water snakes (Enhydris enhydris).

\section{Materials and Methods}

\subsection{Materials}

The tools used in this study include organ storage containers, buckets, trays, rulers, scales, tweezers, surgical scissors, scalpel, microtome, tissue bath, slide warmer, object-glass, cover glass, staining jar, label paper, oven, and a light microscope ( Olympus CX31) equipped with a microphotography ( Olympus BX41).

The ingredients used are snakes taken from the digestive tract, which are in the form of the esophagus, stomach, front small intestine, and back large intestine. Clove oil, physiological $\mathrm{NaCl} 0.90 \%$, Neutral Buffered Formalin (NBF) $10 \%$ solution, alcohol with a concentration of $70 \%, 80 \%, 90 \%, 95 \%$, and absolute, silol, paraffin, Hematoxylin Eosin (HE) dyes, distilled water, running water, and adhesives.

\subsection{Methods}

This research uses exploratory histology method to see the histological picture of the digestive system of water snakes (Enhydris enhydris)

\subsection{Research procedure}

\subsubsection{Sampling}

Sampling was carried out on 3 water snakes (Enhydris enhydris) with a body length of 58-60 cm taken from the waters of the ditches or rice fields around the rice fields in Blang Bintang, Aceh Besar. A sampling of a snake's digestive tract is carried out after the snake has dieted using clove oil. As much as $5 \mathrm{ml}$ of clove oil is dissolved in 1 liter of water. Samples were taken in the form of the esophagus, stomach, small intestine front and back of the large intestine. then each sample is cut $3 \mathrm{~cm}$ long. All parts of the sample to be taken are rinsed with $0.9 \%$ physiological $\mathrm{NaCl}$ solution until clean, then the sample has been cleaved and stretched on mica paper, and put in $10 \%$ NBF fixation solution for 48 hours. Then each sample is labeled and then transferred to a $70 \%$ alcohol solution ( stopping points) until the dehydration process is carried out.

\subsubsection{Histology Preparations}

The histological preparations for the esophagus, stomach, small intestine, and large intestine refer to the Kiernan method [13]. The process begins with tissue dehydration with a multilevel concentration of alcohol $(80 \%, 90 \%$, $95 \%$, absolute and absolute II) for 2 hours each. The tissue was then purified in liquid silol I, silol II, and silol III for 45 minutes respectively. Then the network was infiltrated in liquid paraffin I, liquid paraffin II, and liquid paraffin III for 45 minutes each, and continued with embedding in liquid paraffin until it became a paraffin block (blocking). Furthermore, the tissue block is sliced (sectioning) using a $5 \mu \mathrm{m}$ microtome and the incision is placed in a tissue bath, then taken with an object-glass and then incubated into the Warmer slide.

\subsubsection{Hematoxylin Eosin (HE) Staining}

The coloring begins with the deparaffinization process using silol I for 5 minutes, and silol II for 2 minutes. Furthermore, the rehydration process with alcohol decreases from absolute alcohols I and II, alcohols 96\% I and II, alcohol 90\% every 2 minutes, then put into running water. Then put into hematoxylin solution for 5 minutes, then put into running water and put into acid alcohol once dipped then rinse with running water. After that put into the eosin solution for 5 minutes. Then do the dehydration process again with $96 \%$ alcohol I and II, absolute I and II twice each dip. After that, do the clearing process with silol I and II and III for 3 minutes each, then do the mounting with entelan. Observations were made using an Olympus light microscope and followed by taking photographs [13].

\subsection{Parameters}

The parameters observed in this study were the layers found in the esophagus, stomach, small intestine, and large intestine namely mucosal tunica, submucosal tunica, muscularis tunica, and serous tunica.

\subsection{Data analysis}

Data obtained from the results of this study were analyzed descriptively and presented in the form of images.

\section{Results and Discussion}

\subsection{Histology of Water Snake Digestion System}

The parameters observed in this study were the layers found in the esophagus, stomach, small intestine, and 
large intestine namely mucosal tunica, submucosal tunica, muscularis tunica, and serous tunica.

The results of the observations in the microscopic structure of the histology of the system digestive snake water are not much different from the reptiles in general. System Digestive snake water obtained that are arranged on four layers, namely the tunica mucosa, tunica submucosa, tunica muscularis, and the tunica serosa. Tunika mucosa consists of lamina epitelia, lamina propria, and the lamina muscularis mucosa. The tunica submucosa consists of a network of connective with vascular blood lymph and nerve. The tunica muscularis is composed of muscle circular (circular ) and muscle lengthwise (longitudinal), and the tunica serosa consists of a network of connective thin.

\subsubsection{Esophagus}

Oesophageal snake water has tunica mucosa that forms folds extending like villi which consist of lamina epitelia, lamina propria, and the lamina muscularis mucosa. The epithelium lamina is composed of a layer of cylindrical epithelium and goblet cells. Uriona et al. [14]; Cakici and Esra [7] mentions that the lining mucosa of the esophagus is composed of cells of columnar ciliated and cell goblet. Cundall et al. (2014)[15], lamine propria of the esophagus of species of snakes are usually very thin, and many contain capillaries. Muscularis mucosa is composed of layers of cells muscle plain are not uniform. Layers of submucosal esophageal snake have a thickness that varies, layer muscularis usually consists of cells muscle smooth circular which is surrounded by muscle lengthening, and lamina serosa esophagus of snake is like tissue connective loose lined by epithelial squamous. The histology of the water snake's esophagus is shown in Figure 1.

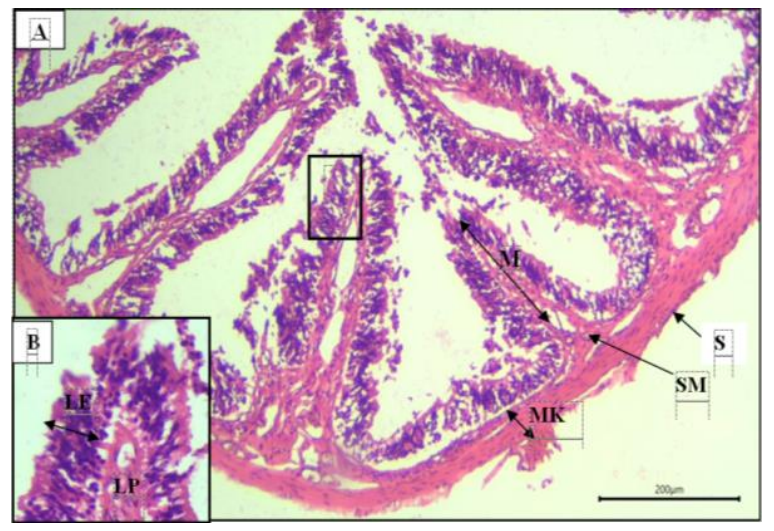

Figure 1. Histology of water snake esophagus. Mucosal tunica (M), submucosal tunica (SM), muscularis tunica ( MK), serous tunica (S), epithelial amine (LE), and lamina propria (LP). HE coloring. (A) Magnification of $100 \mathrm{X}$ and (B) magnification of $400 \mathrm{X}$.

The esophagus has an elongated mucosal fold that plays a role in increasing the diameter of the esophagus suddenly and facilitates the movement of large-sized foods swallowed into the stomach. Cells in the esophagus are only mucous-producing cells $([16,17]$.

\subsubsection{Stomach}

Tunica mucosa of the water snake consists of 1 amine epithelium and lamina propria. The epithelium lamina is composed of a cylindrical epithelium layer, there are many gastric glands in the lamina propria. Mackessy and Loise [18] mention that the snake's stomach produces mucous glands in large numbers, which serves to assist the digestive process. Gastric glands in the mucosa section produce hydrochloric acid and pepsinogen, both of which are effective in separating large protein molecules [17]. Hydrochloric acid breaks down pepsinogen into pepsin which remodels proteins into peptones (polypeptides) [19].

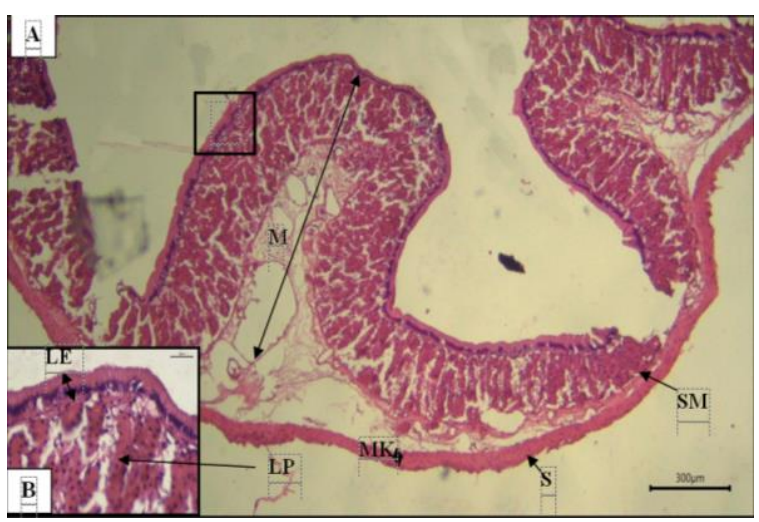

Figure 2 . Histology of water snake hulls. Mucosal tunica (M), submucosal tunica (SM), best selling tunica (MK), serous tunica (S), epithelial amine (LE), and lamina propria (LP). HE coloring. (A) Magnification of $100 \mathrm{X}$ and (B) magnification of $400 \mathrm{X}$.

Gastric submucosal tunica is a thin section located in the profundal part of the tunica mucosa. The submucosal tunica is composed of loose connective tissue and blood vessels. The gastric muscularis is composed of circular and longitudinal muscle. Muscularis usually experience thickening because this part plays an active role to push food through the vulva loop (the limiting valve between the stomach and intestine) and is passed on to the intestine. Histology of the water snake's stomach is shown in Figure 2.

\subsubsection{Small intestine}

Tunica mucosa of the water snake forms a longitudinal elongation towards the lumen called intestinal villi, consisting of lamina epithelium and lamina propria. The epithelium lamina from the small intestine of water snakes has differences with other reptiles such as in water lizards that have epithelial lamina with a cylindrical cell layer, whereas in water snakes found that is composed of layered cylindrical cells, with microvilli (limbus penicillatus) and goblet cells. The microvillus is an extension of the cytoplasm which increases nutrient absorption. The lamina propria of the water snake's small intestine looks like a thin layer of connective tissue and there are many lymphocytes. According to Diaz et al.[20], lymphocytes found in lamina propria play a role in specific defense mechanisms in the digestive tract. 
The epithelial lining of the snake's small intestine is typical of the functional mucosal epithelium as is known from many other vertebrates, the mucosal epithelium is a single-layered columnar epithelium [21]. Some types of snakes have mucous glands along the submucosa [22]. Ahmed et al [9] mentioned that the mucosal muscularis is very thin and consists of one smooth layer. In this study tunica submucosa tunica not found the brunner gland and liberkun gland, because kripta from the small intestine of snakes is not formed. Muscular tunica is composed of circular and longitudinal muscles that play a role in the process of encouraging food to be passed. Serous tunica has connective tissue that encloses the entire outer portion of the intestine. Histology of aquatic small intestine is shown in Figure 3.

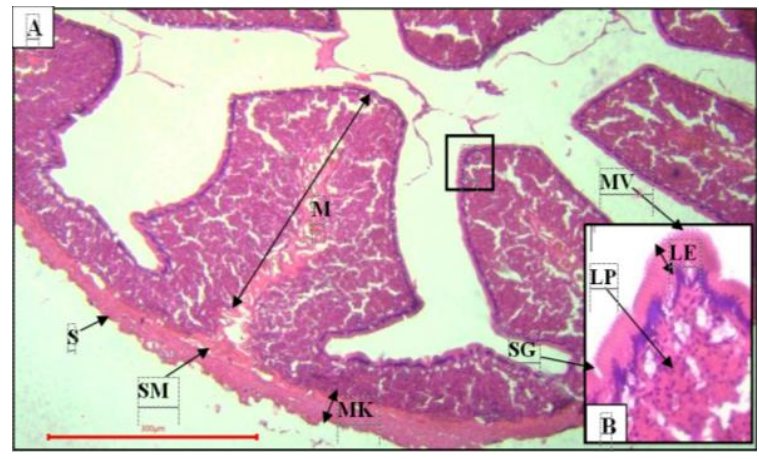

Figure 3. Histology of aquatic small intestine. Mucosal tunica (M), submucosal tunica (SM), muscularis tunica (MK), serous tunica (S), Lamina epithelium (LE), goblet cells (SG), microvilli (MV), and lamina propria (LP). HE coloring. (A) Magnification of $100 \mathrm{X}$ and (B) magnification of $400 \mathrm{X}$.

\subsubsection{Colon}

The histological feature of the large snake large intestine consists of a cylindrical epithelium layer with villous folds extending toward the lumen. Mucosal tunica consists of lamina epithelium and lamina propria. The lining of the large snake's large intestine is not far from the small intestine. Cakici and Esra [7] state that the epithelial layer of the large intestine consists of layers of columnar epithelial cells and is in the form of small folds, and goblet cells are spread between epithelial cells.

According to Hamny et al.[23] in terms of food types, herbivorous reptiles have a morphological composition of the large intestine that is different from carnivorous reptiles. Herbivorous reptiles tend to have a cecum, whereas carnivorous reptiles do not have cecum in the large intestine. Cecum itself serves as a storage place for food to be digested again. The histology of the large snake large intestine is shown in Figure 4.

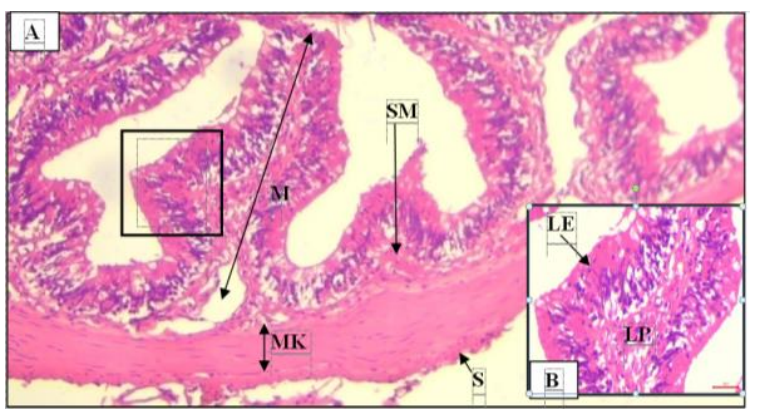

Figure 4. Histology of water snake large intestine. Mucosal tunica $(\mathrm{M})$, submucosal tunica (SM), best selling tunica (MK), serous tunica (S), epithelial amine (LE), and lamina propria (LP). HE coloring. (A) Magnification of $100 \mathrm{X}$ and (B) magnification of $400 \mathrm{X}$.

\section{Conclusions}

The histological structure of the digestive system of water snakes is not much different from the digestive system of reptiles. In intestinal smooth snake is not in encounter gland brunner and liberkun . Lamina epitialis on intestinal smooth snake composed on epithelial cylindrical layered.

\section{References}

1. Putranto DI, Yuda P, Zahida F : Keanekaragaman reptil impor di Yogyakarta. Jurnal Fakultas Teknobiologi Universitas Atmu Jaya Yogyakarta. 2013.

2. Yudha DS, Eprilurahman R, Muhtianda IA, et al. : Keanekaragaman spesies amfibi dan reptil di kawasan Suaka Margasatwa Sermo Daerah Istimewa Yogyakarta. Jurnal MIPA. 2015 ; 38(1):8-13.

3. Yudha DS, Eprilurahman $\mathrm{R}$, Jayanto $\mathrm{H}$, et al. : Keanekaragaman jenis kadal dan ular (Squamata : Reptilia) di sepanjang sungai Code, Daerah Istimewa Yogyakarta. Biota. 2016; 1(1):31-38.

4. Asri ASK, Yanuwiadi, Bagyo: Persepsi masyarakat terhadap ular sebagai upaya konservasi satwa liar pada masyarakat dusun Kopendukuh, desa Grogol, kecamatan Giri, kabupaten Banyuwangis. J - PAL. 2015; 6(1): 42-47.

5. Reza F, Tjong DH, Novarino W : Karakteristik morfologi ular famili Elapidae dikampus Universitas Andalas Limau Manih Padang. Journal of Sainstek.2016; 8(2):135141.

6. Amri K,Sihombing T: Mengenal \& Mengendalikan Predator Benih Ikan. Gramedia Pustaka, Yogyakarta. 2008.

7. Cakici O, Akat E: Some histomorphological and histochemical characteristics of the digestive tract of snake-eyed lizard, ophisops elegans menetries, 1832 (Squamata: Lacertidae). North - Western Journal Of Zoology. 2013; 9(2):257-263.

8. Prawirohartono S :Sains Biologi, Jilid 2A. Bumi Aksara, Jakarta. 1995.

9. Ahmed YA, Hafez, AAE. Elet al.: Histological and histochemical studies on the esophagus, stomach, and small intestines of Varanus niloticus. J. Vet. Anat. 2009; 2(1):35-48.

10. Eroschenko VP : Atlas Histologi Difore Dengan Korelasi Fungsional. Penerbit Buku Kedokteran EGC, Jakarta. 2015. 
11. Wahyuni S, Zuchri, Hamny, et al.: Studi histokimia sebaran karbohidrat usus biawak air (Varanus salvator). Akta Veterinaria Indonesia.2015; 3(2):77-84.

12. Hamny H, Iqbal M, Wahyuni S, et al. : Studi anatomis dan histologi pankreas biawak air (Varanus salvator).Jurnal Kedokteran Hewan, 2016 ; 10(2):153-156.

13. Kiernan JA: Histological \& Histochemical Methods: Theory and Practice. 2nd ed. Pergamon Press, Oxford. 1990.

14. Uriona TJ, Farmer CG, Dazely J, et al. : Structure and function of the esophagus of the American alligator (Alligator mississppiensis). The Journal of Experimental Biology. 2005; 208: 3047-3053.

15. Cundall D, Tuttman CClose M : A model of the anterior esophagus in snakes, with funtional and developmental implication. The Anatomical Record.2014297:586-598.

16. Agbugui $\mathrm{MO}$ :The mouth and gastro-intestinal tract of pomadasys jubelini (Cuvier, 1830) in the new calabarbonny river, River state, Nigeria. Researcher2013; 5(12):190-195.

17. Naser MN, Mustafa T:Histological and histromorfomertric aspect of the digestive system of the taki fish, channa puncatus (Bloch. Schneider 1801) Bangladesh. J. Zool. 2006 ; 34(2):205-212.
18. Mackessy SP, Baxter LM Bioweapons synthesis and storage : the venom grand of front fonged snakes. Zoologischer Anzeiger 2006;147-159.

19. Djarijah APakan Ikan Alami. Kanisius, Yogyakarta. 1995.

20. Diaz AO, Garcia AM, Figuero DEet al :The mucosa of the digestive tract in micropogo nias furmeri; a light and alectron microscope apporoach. Anat. Hiatol. Embryol. $2008 ; 37(4): 251-256$

21. Elliott JR :Overview of reptile biology, anatomy, and histology. Infectious disease and pathology of reptiles. New York, Taylor and Francis Group: 2007; 1-25.

22. Starck JM, Beese KStructural flexibility of the intestine of burmese phython in response to feeding. The Journal of Experimental Biology.2001 ; 325-335.

23. Hamny H, Mulyani S, Masyitha D, et al.: Morfologi anatomi dan histologi usus biawak air (Varanus salvator). Jurnal Veteriner. 2015; 16(2):152-158. 